Athens Journal of Humanities \& Arts - Volume 8, Issue 4, October 2021 - Pages 325-340

\title{
"Because No One Can Seize me from Behind": Sir Christopher Hatton's Double Portrait and Elizabethan Textual Paintings
}

\author{
By Elisa von Minnigerode
}

\begin{abstract}
Many researchers have emphasised the special use of inscriptions and texts in Tudor paintings. ${ }^{1}$ Especially in Elizabethan times, emblematic images emerge and contain texts which present riddles to their audience, address an implicit or explicit beholder, and also give information about their own function. The enigmatic double-sided portrait of Christopher Hatton serves as an outstanding example of the various relations that texts and images form in this era. Two elements of its composition will be discussed here: the inscription and the depiction of Father Time, both on the verso-side. One, a textual element, forms a unit with the other, a pictorial element. On their own and in combination, both built up a reference to emblem books and sources outside the picture and contextualise themselves in humanistic discourses about opportunity and time. Thus, their exclusive presentation forms a dialogue with the beholder and opens up a meta-level of artistic expression. The ancient pictorial tradition of the God Kairos is addressed in the combination, while it labels itself as a depiction of time. Overall, the object briefly examined in this study is an outstanding example of Elizabethan artistic culture and remains a desideratum in art history.
\end{abstract}

\section{Introduction}

The Elizabethan era has mainly been described as a period "of immense political and religious changes throughout Europe." While literature and music flourished at that time and are well-known today, its paintings are called "curiously unfamiliar". ${ }^{2}$ Especially of portraiture, often called the dominant genre of the English Renaissance, many samples exist today. While an "Englishness" in painting was not yet developed, the portraits designed during the Virgin Queen's reign delivered an unrepeated perceptual quality and took on a completely underestimated role in English art history. Symbolic strategies of depiction emerged, combining mediums and different layers of meaning, creating likeness, representing status, wealth, diplomacy, and power, or proving loyalty. Artists such as Hans Eworth and George Gower created singular emblematic and

"Research Associate, University of Konstanz, Germany.

1. Juliet Flemming, "Wounded Walls: Graffiti, Grammatology, and the Age of Shakespeare," Criticism 39, (1997): 1-30; Roy Strong, The Elizabethan Image: Painting in England 1540-1620 (London: Tate Gallery Publications, 1969).

2. Karen Hearn, "Introduction," in Dynasties: Painting in Tudor and Jacobean England 1530-1630, edited by Karen Hearn (Peterborough: Tate Publications, 1995), 9-10. 
narrative portraits of English courtiers at Queen Elisabeth's court, well known in the discipline of art history. ${ }^{3}$ English portraits show exceptional qualities, unique for European painting at the time: the use of inscriptions, referencing literature within the picture, as well as details of the composition, all these create a narrative aspect and charge the paintings emblematically. Artistic encryptions and codifications create a "slippery secret world of private allusions" and satisfy a "fondness" for puzzles and allegories. ${ }^{4}$

The complicated portrait of Christopher Hatton is one of the most illustrious emblematic paintings and demonstrates the exceptional qualities of images at that time. ${ }^{5}$ Hatton, Elizabeth I's Lord Chancellor, is surrounded by a horoscope. Inscriptions and additional narrative scenes are added to the composition. Painted front and back, it is an image not only to be read as a picture but also to be physically examined as a material object. Its design reveals a complex interplay: the practice of linking the front and the reverse, creating a relation between the material and the depicted. Since both sides cannot be seen at the same time, the reception becomes not only intellectually challenging but physically demanding as well. While several exhibitions and catalogues have acknowledged the portrait's unique quality, only a few researchers have discussed it in detail. ${ }^{\text {These }}$ Thorks already give a good idea of the complexity that this image has. However, a complete interpretation of the iconography, how the portrait was presented and commissioned is still missing.

The present study aims to discuss the outstanding relation that text and image built up in this example. To narrow that approach down, two elements of the composition will be picked out and analysed: the cryptic inscription at the back of the portrait and the representation of Father Time on the same side. How do they reference each other, and how is their connection to be understood? What kind of perception is demanded from the beholder through the distinct combination of a textual and pictorial element? Because I can only discuss singular aspects of the picture here, this study cannot claim to be a complete examination of the object. Nevertheless, it will help to lay the groundwork for further research of this rich and secretive example of Elizabethan painting.

3. Erna Auerbach, Tudor Artists: A Study of Painters in the Royal Service and of Portraiture on Illuminated Documents from the Accession of Henry VIII to the Death of Elizabeth I (London: Athlone Press, 1954).

4. Hearn, "Introduction," 9-10; Mario Praz, Studies in Seventeenth-Century Imagery (Rome: Edizioni di Storia e Letteratura, 1975), 205-2013.

5. Unknown, Double-Sided Emblematic Portrait of Sir Christopher Hatton, c.1580, oil on panel, $96 \times 72.3 \mathrm{~cm}$, Northampton Museum and Art Gallery.

6. The strongest approach is given by C. W. Moseley, "A Portrait of Sir Christopher Hatton, Erasmus and an Emblem of Alciato. Some Questions," The Antiquaries Journal 86 (2006): 373-379. Illustrations are given by Tarnya Cooper, Elizabeth I $\mathcal{E}$ her People (London: National Portrait Gallery, 2013), 88-89. 


\section{Literature Review and Methodology}

For a long time, art-historical research of the Tudor era mainly focused on authorship and artists. More recent works have pointed out the qualities of the objects themselves and worked out their significance in a context of society and time of religious reformation. ${ }^{7}$ Singular portraits have been examined individually rather than generalising them in groups. As one example, Margaret Aston has famously shown in The King's Bedpost how complex an English $16^{\text {th }}$-century painting works in the interaction of inscription and images and how prints were used as sources for the composition. ${ }^{8}$ Text and inscriptions have vastly been identified as symptomatic elements of Elizabethan pictures, which typically refer to the portrait's sitter. ${ }^{9}$ They often contain the sitter's age, sometimes a motto - a kind of slogan of the portrayed person - and the date.

Consequently, these textual elements function as a support of portraiture's function of documenting the sitter in a certain state of his life. Inscriptions as components of the portrait have also been adapted in miniature-making at that time. ${ }^{10}$ Studies like those presented by Roy Strong are very early approaches which analyse the objects by paying attention to the texts in the pictures and valuing the text as more than just an addition to the painted scene. ${ }^{11}$ Yet, the broad spectrum of texts in Tudor paintings and their specific, sometimes individual functions depend on the objects themselves and have rarely been studied. With Christopher Hatton's double-sided portrait as a case-study, this paper's aim is to, firstly, give an example of a highly individual and carefully designed model of the Elizabethan textual image and secondly, to give an understanding of the all-over text-image relation of this literal-flourishing epoch.

At first, a close examination of the text will be presented, and sources of its origin will be discussed. Secondly, the inherent iconography of Father Time will be laid out so that it can be put into connection with the inscription. The question will arise if text and image can be treated separately or, instead, if they form a corresponding bond that creates a special object-function. In a third step, this

7. Tarnya Cooper, Citizen Portrait. Portrait Painting and the urban elite of Tudor and Jacobean England and Wales (New Haven: Yale University Press, 2012), 20-25. Margaret Aston, "Gods, Saints and Reformers: Portraiture and Protestant England," in Albion's Classicism: The Visual Arts in Britain 1550-1660, edited by Lucy Gent (New Haven: Yale University Press, 1995), 181-220.

8. Margaret Aston, The King's Bedpost (Cambridge: Cambridge University Press, 1996).

9. Hearn, "Introduction," 10.

10. Lindsey Cox, "Pleasing 'the Common Sort Exceedingly Well': An interdisciplinary Repositioning of the British Portrait Miniature c. 1520-1650," PhD Dissertation (University of Kent, 2018), 171.

11. Roy Strong, "Elizabethan Painting: An Approach through Inscriptions - Robert Peake the Elder," The Burlington Magazine 105 (1963): 53-57. 
study will look at the role of the audience. Who was the target audience of such an object, and what sort of perception was expected from them? Finally, examining the text-image relation of Christopher Hatton's double-sided portrait will provide a closer reading of this highly complex and understudied image and present an example of how texts and images construct the object beyond the material. However, before a portrait can be examined thoroughly, the sitter has to be addressed as well.

\section{The Sitter and his Portrait: Christopher Hatton}

Christopher Hatton, who has been branded as "the dancing chancellor" by contemporary authors, is one of the less famous figures of Elizabethan court. ${ }^{12}$ Not much is known about his upbringing and entering court. More prominently, his development into one of the Queen's favourites has been discussed and shown in several biographical works. ${ }^{13}$ Hatton and the Queen had a close but not exclusive relationship. Like other of her beloved courtiers, for example, the Earl of Leicester, their connection can be best described as filled with "an emotional quality". ${ }^{14}$ It is known that she used nicknames for him - as she did for other men at her court, e.g. she called Lord Burghley her "spirit"15 - which he responded to and used himself. In letters to her, Hatton called himself her "sheep" and signed his letters with "Lyddes". They sent presents and tokens to each other regularly, ${ }^{16}$ for example, a "true love's knot", 17 and the Queen used to pay him distinctive attention when he fell ill. ${ }^{18}$ In their correspondence, both used cyphers, possibly as signatures or reminders. ${ }^{19}$ Additionally, Hatton used special writing of the word "EveR", capitalising the first and the last character whenever he wrote it in letters to the court, thus referring to the Queen as 'Elizabeth Regina'.20 Overall, it seems that he had a particularly close position to the Queen, which was a known

12. Eric St John Brooks, Sir Christopher Hatton. Queen Elizabeth's Favourite (London: Cape, 1947), 50-59.

13. Nicholas Harris Nicolas, Memoirs of the Life and Times of Sir Christopher Hatton, K. G. (London: Bentley, 1847); Malcolm Deacon, The Courtier \& The Queen: Sir Christopher Hatton and Elizabeth I (Northampton: Park Lane Publishing, 2008).

14. Alice Gilmore Vines, Neither Fire nor Steel. Sir Christopher Hatton (Chicago: NelsonHall, 1978), 20.

15. Thomas Wright, Queen Elizabeth and her times, Original Letters Selected from the Private Correspondence of Burghley [and Others], Volume 2 (London: Henry Colburn, 1838), 201.

16. Vines, Neither Fire nor Steel, 15.

17. Nicolas, Memoirs, 414.

18. Nicolas, Memoirs, 22-29.

19. Illustrated in Nicolas, Memoirs, 25, 28 and 156.

20. Nicolas, Memoirs, 29 and 443. 
fact to her circle. And at the same time, he was regarded as the one medium to communicate her wishes to others. ${ }^{21}$ His unique position already showed when he just entered the court. It was said that the Queen developed favour for him when she saw him dancing at festivities, which caused him to carry his already mentioned nickname of "the dancing chancellor" and formed his historical reputation for a long time. Although not having a degree or academic education, Hatton was very quickly chosen to be a member of the Privy Council. This was an obscure body of carefully chosen men who administrated the government's routine business and held its meetings in secret. ${ }^{22}$ This position would prepare him to become Vice-Chamberlain and later Lord Chancellor. He acquired many estates during his lifetime and most famously rebuilt his family home, Holdenby, in Northamptonshire. He died in 1591, highly in debts and without leaving any children and was never married.

Several portraits of Christopher Hatton from his lifetime survived. Next to a 'textual' portrait of him, created at his appointment as Chancellor of the University of Oxford in the National Portrait Gallery (NPG) ${ }^{23}$, two Miniatures by Hilliard exist, one in the NPG and one in the Victoria and Albert Museum. The most interesting object, however, is the already mentioned double-sided-portrait (Figures 1 and 2). Its provenance is one with many question marks. It is first documented in an auction catalogue from 1929 when it went in the museumcollection at Northampton. Until 2020, it was exhibited for several years at the National Portrait Gallery in London. By whom and when the picture was painted is not clear yet. The most prominent dating-approach was done by Arthur Beer, who has examined the image using astronomical methods and interpretation. ${ }^{24}$ While his approach was not left without criticism, his approximate dating around 1581 is accepted in research. The most significant clue in this matter seems to be the coat of arms on the top right corner. Because of its specific design, it can be assumed that the painting was created before 1588 when Christopher Hatton was made Knight of the Garter (K.G.). As K.G., the garter would have been included in his signs, probably round his shield, which it is not in this particular depiction.

21. Nicolas, Memoirs, 50 and 55.

22. Nicolas, Memoirs, 17.

23. Unknown: Sir Christopher Hatton as Chancellor of the University of Oxford, ca. 1588, oil on panel, 78,7 x 6,35 cm, National Portrait Gallery London.

24. Arthur Beer, "Astronomical Dating of Works of Art," Vistas in Astronomy 9 (1968): $177-223$. 

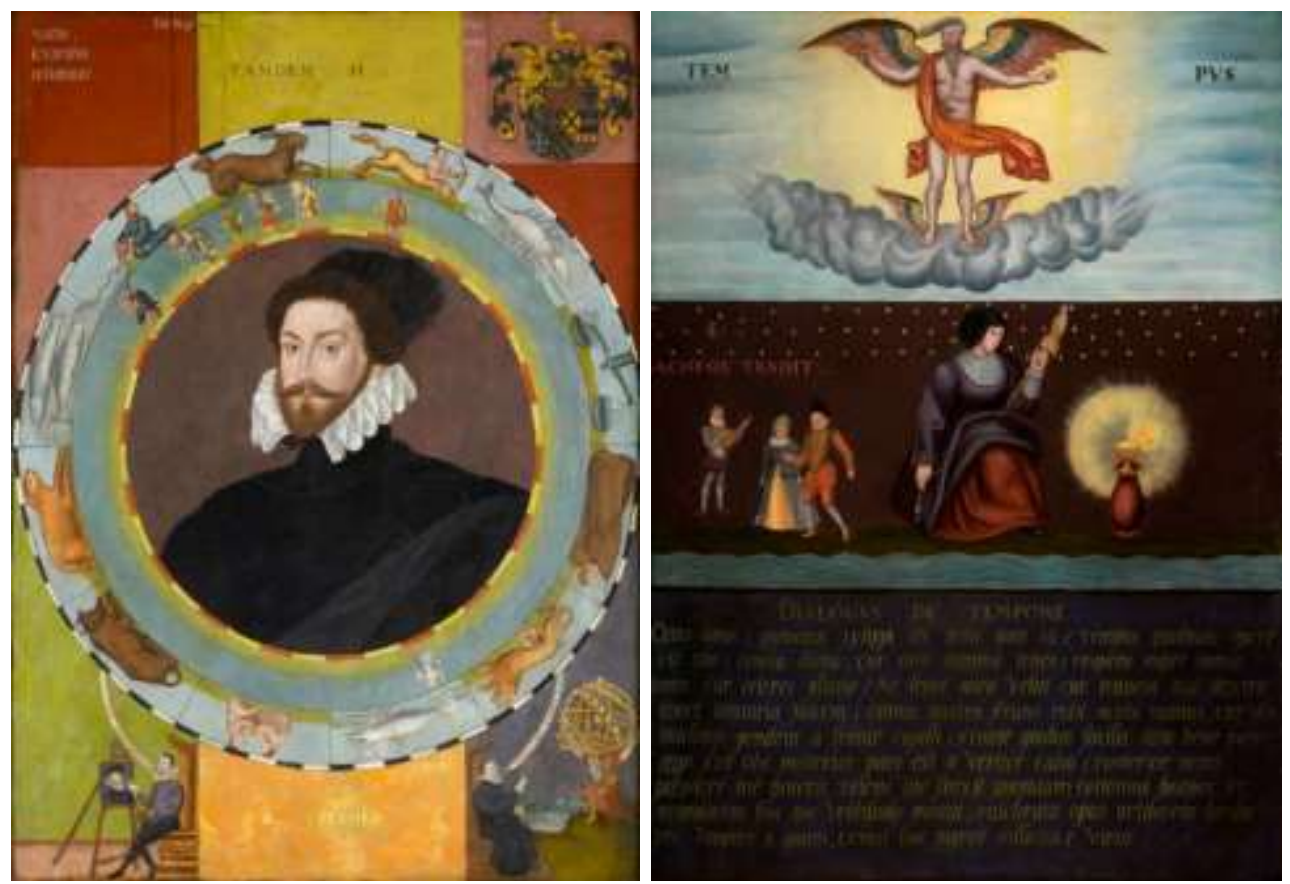

Figures 1 and 2. Unknown: Sir Christopher Hatton, c. 1580, Oil on Panel, $96 \times 72.3 \mathrm{~cm}$, Northampton Museums and Art Gallery, Front-Side (left) and Backside (right) Source: Northampton Museums and Art Gallery.

The portrait-site of Sir Christopher's painting is cryptic at first sight. In the middle of the composition, the later Lord Chancellor is situated in a circle surrounded by a horoscope and astrological rings. Four different circles surround him directly, including the signs of the zodiac and the decans. Hatton's arms are mounted in the top right corner, while two scenes complete the composition in the lower part: A painter working on an easel painting with a portrait of a bearded man, which seems to resemble Hatton and an astrologer with an astrolabe. Several inscriptions are added to the scenery. Both figures at the bottom have labels drawn from their mouths, reminding the modern beholder of word bubbles. The astrologer's label says "[ae]ternitati finiti[s?]" which means either "he destined to eternity" or "he destined from eternity"..25 The painter's label, on the other hand, says "[ae]ternitati pinxit," meaning "he painted for eternity." The vertical yellowish squares in the middle of the picture contain mottos. At the bottom, the painted area is damaged and thus cryptic, "S[...]i[...]Spesmea" is visible, and in the top centre "Tandem Si" is written, a motto Hatton used in his later career and to which a useful translation is yet missing. ${ }^{26}$ In the top-left, three Latin words are listed, one below the other in invisible rows saying "Natus", "Exaratus", and "Inhumatus" (Born, Raised, Buried). Going to the centre "Die", "Mense", and "Anno" written into columns, complete the left side, while on the right side next to the coat of

25. Moseley, "A Portrait of Sir Christopher Hatton," 373.

26. Brooks, Sir Christopher Hatton, 392. 
arms "Miles Creat[us]: 15" is also written in a column. This part of the painting has been interpreted as incomplete. It is thought to have been intended for, according to the Latin inscription, Hatton's birthdate, date of rising - as Knight, for example - and date of death. If this is an appropriate assumption and why it was left unfinished is not known so far.

The back of the painting shows an allegorical scenery with Father Time standing at the top of the depiction. Beneath him, a woman with a distaff and two figures dancing with a violinist playing music for them are visible. On the right side of this middle-field, a pillar with a chalice spreading spouts of light adds another cryptic element to the composition. While the dancers have commonly been interpreted as a referral to Hatton's reputation as an exceptional dancer and the anecdote that he caught the eyes of Queen Elizabeth while dancing, no conclusion for the chalice has been presented so far. ${ }^{27}$ The rest of the backside is filled with an inscription at the bottom, a cryptic text in Latin on which will be focused on here:

DIALOGUS DE TEMPORE/cuius opus; quondam lysippi dic mihi guis tu; tempus quidnam operae/est tibi; cuncta domo, cur tam summa tenes; propero super omnia/pernix, cur celeres plantae; me leuis aura vehit cur tenuem tua dextra/tenet tonsoria falcem; omnia nostra fecans redit acuta manus, cur tibi/tam longi pendet a fronte capilli, fronte guidem facilis sum bene posse/capi cur tibi posterior pars est a vertice calva; posterior nemo/prendere me poterit, talem me finxit quondam sytiomus hospes, et/monitorem hoc me vestibulo posuit, pulchrum opus artifecem laudat/pro juppiter o guam, debuit hoc pigros sollicita[r]e viros. ${ }^{28}$

This description should already have shown the complexity of the object's design and its potential for investigation. What will be focused on here are the

27. Moseley interprets it as a lamp while Cooper suggests that it is a golden chalice representing the human soul. Moseley, "A Portrait of Sir Christopher Hatton," 378, n. 3.

28. Thanks to restoration work the object is in good condition for perception and the text on the back can be easily read in images. However, multiple publications give a transcript of the text, while not all of them accurate and sometimes misread letters, which is certainly due to the quality of reproductions from the painting. The "sytiomus" in the third line from below in this text is an actual spelling mistake and should be "sycionius" (of Sicyon). Moseley has already transcribed it this way, while close inspection of the painting shows that it is really written as "sytiomus". This leads to the suspicion that whoever painted or re-painted the letters, remembering the condition of the object, were not fully aware of what they were writing. This is, however, no clue into a certain direction as artists and even patrons in $16^{\text {th }}$ century England were not always as fluent in Latin as one might assume. 
Latin text and the connection it builds up to the figure of Father Time. ${ }^{29} \mathrm{~A}$ fruitful examination of the depicted personification and an interpretation of the object as a whole cannot be accomplished in this paper. However, a close look at this particular text-image-relation of the painting should be understood as a contribution to solving the painting's history.

The following questions about the text-image-relation on the backside of Christopher Hatton's double-sided painting will be addressed: Is the text somehow describing the depicted? Or is the painted scene an illustration of the written text? This study strives to focus on the text and the image to analyse the dialogue that these two form in this particular object. The double-sided status will lastly show to be a material status that is strengthening the reciprocal relationship that text and image built up here, which is outstanding for the highly textual images in the Elizabethan era.

\title{
Hinting at the Unseen: The Inscription of the Backside
}

Looking at the inscribed text itself is, as such, already a clue to the image's object-history and status. It can be translated into English as:

\begin{abstract}
A Dialogue of Time
Whose work are you? Of Lysippus, once. Tell me who you are. Time. What do you do? I subdue all things. Why do you so occupy the highest place? Swift, I hurry over all things. Why are your feet swift? The light breeze carries me. Why does your shearer's right hand hold a slender crescent? My severe hand, as it cuts, makes all things mine. Why do long locks hang from your forehead? From the front, I am easy to be held fast. Why is your posterior part bold at your head? No one posterior can seize me. Of that kind [Lysippus] of Sicyon created me once, visitor, and placed me in this entrance hall as a lesson, a beauteous work praises the artist, oh Jupiter, oh that this was destined to stir up lazy men. ${ }^{30}$
\end{abstract}

29. The front-side inscriptions will not be considered on here due to their incompleteness. Especially the "S[...]i[...] Spesmea" is still a riddle to research. While interesting, it does not fit to the subject of text and image that is addressed here in the first place. Additionally, the object's condition, as said before, makes it hard to identify the motto without a doubt. The area around the line is highly damaged, thus incomplete and would ask for support from art technological research. To show how differently it can be read and completed, Beer presented three possibilities, Beer, "Astronomical Dating," 215. For an elaboration on the motto see Moseley, "A Portrait of Sir Christopher Hatton," 375.

30. The translation provided here is based on the translation of Moseley, "A Portrait of Sir Christopher Hatton," 378, n. 4; and Cooper, Elizabeth I $\mathcal{E}$ her people, 86. Misreadings have been corrected though while alterations were made to provide a more accurate, though less elegant, version of the original Latin words and structure. 
The text being written in Latin is generic for the intellectual culture at the Elizabethan court. Moseley and Cooper have shown that this text is unmistakeably relying on a poem printed in Andrea Alciato's Emblem Book (Figure 3). ${ }^{31}$ The entry for "In Occasionem" shows the Latin text in verse, and Moseley has logically demonstrated that there is enough similarity between the two to set them alike when put into verse-form. ${ }^{32}$ Here, the examination is going a step further:

Not only is the text on the image resembling a contemporary emblem book, but the text itself is also of ancient origin and is indeed a variation of the infamous statue of Kairos, which was built by the ancient sculptor Lysippus (400 B.C.). The inscription already hints at this connection when it says the ancient sculptor's name, although one must know who he is to understand what is written. The now lost sculpture was said to have stood in front of Lysippus house in Sycion and had a later added epigram carved in its base, which is said to have been by Posidippuss of Pella (ca. 300 B.C.). As it survives in the Greek Anthology (16.275), this epigram resembles the text of Hatton's portrait in form and content. ${ }^{33}$ Moseley has already stated that Alciato's poem is itself a translation from the Greek Anthology-epigram; thus, the inscription on the painting could have been taken from this source independently. Moseley shows further how many other emblem-books in the $16^{\text {th }}$ century used that poem. ${ }^{34}$ Especially interesting is the version in Geoffrey Whitney's A Choice of Emblem, which was published 1586 in Leiden and presents an English translation of Alciato's "In Occasionem" (Figure 4). ${ }^{35}$ The publishing-year makes it uncertain if the portrait was not completed before Whitney's book came out, but also because Whitney's poem is in English, it does not qualify as a source for the portrait's text. ${ }^{36}$ However, it is crucial to state how the topic of "Occasion" or "Fortune" is present in English discourse and

31. Andrea Alciato, Emblematum liber (London: Scolar Press, 1995), 14-15.

32. Moseley, "A Portrait of Sir Christopher Hatton," 375-376.

33. "Who and whence was the sculptor? From Sikyon. And his name? Lysippus. And who are you? Time who subdues all things. Why do you stand on tip toe? I am running. And why have you a pair of wings on your feet? I fly with the wind. And why do you hold a razor in your right hand? As a sign to men that I am sharper than any sharp edge. And why does your hair hang over your face? For him who meets me to take me by the forelock. And why in heaven's name, is the back of your head bald? Because none of whom I have once raced by on my winged feet will now, though he wishes it sore, take hold of me from behind. Why did the artist fashion you? For your sake, stranger, and he set me up in the porch as a lesson." Simona Cohen, Transformations of Time and Temporality in Medieval and Renaissance Art (Leiden: Brill, 2014), 201-202.

34. Moseley, "A Portrait of Sir Christopher Hatton," 376-377.

35. Geoffrey Whitney, Choice of Emblemes (London: Lovell Reeve, 1866), 181.

36. This assumption is made because of the unlikelihood that a poem in English would be translated back into Latin with a Latin version existing. Moseley also notices that the portrait's version is closest to Alciato's, Moseley, "A Portrait of Sir Christopher Hatton," 377. 
shows how largely humanistic circles in England perceived Alciato. ${ }^{37}$ This becomes important when we go one step further to think about the portrait's relation with the audience. The connection of the figure Karios to the depicted figuration of Father Time in Hatton's portrait will be discussed later. However, it can be asserted that the connection between the subject of "Occasion", which was made in the resemblance in the picture's inscribed poem and the ancient figure of Kairos, who is also called opportunity, becomes stronger through these findings. ${ }^{38}$

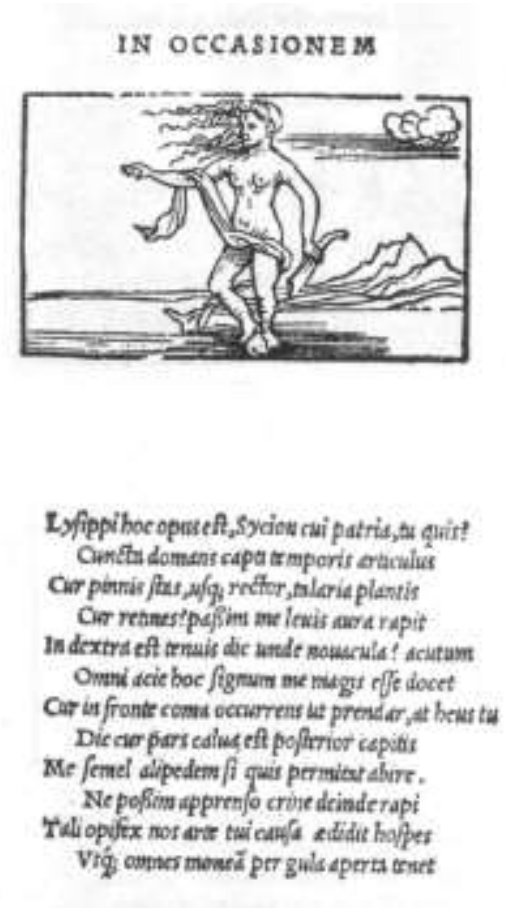

Figure 3. Alciato's "In Occasionem" Source: See Note 31.

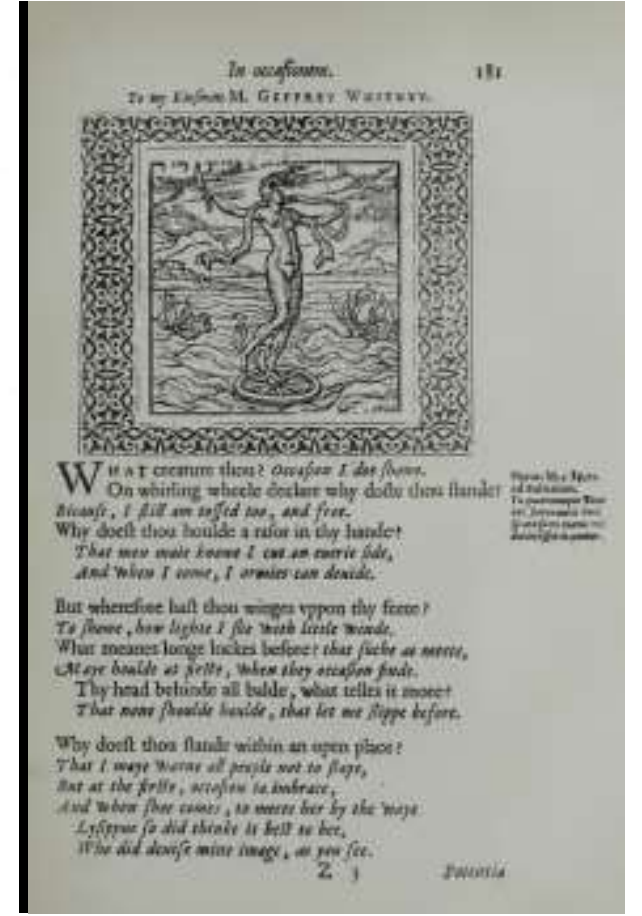

Figure 4. Whitney's "In Occasionem" Source: See Note 35.

Knowing now that the text is not an original invention for the picture, but has its source either in emblem books or in the Greek anthologies in reference to Lysippus' Kairos, gives a hint to understanding the connection of the text to the portrait as an object. Rather than grasping the text as a sort of voice from the image, it becomes a meta-text that speaks about the object's references and the object itself at the same time. The text points to sources outside of the picture as such, which are not apparent to the beholder without a piece of specific knowledge. Especially the part where the answers begin to describe the figure's appearance is interesting. Speaking of a figure with long hair from its forehead and a bold back of his head lets the beholder look up to the father time personification at the top of the panel. When the text says "no one posterior can

37. Peter Daly, Andrea Alciato in England: Aspects of the Reception of Alciato's Emblems in England (New York: AMS Press, 2013).

38. Cohen, Transformations of Time, 199. 
seize me", simultaneously meaning "no one who is late" and "no one who is behind", the object seems to not only refer to the subject of time but also its own materiality and unique construction. While no one who looks at the backside of the painting can seize its full extend because there is also the front, no one who is late, meaning no one who is born too late - or hasn't gained enough knowledge until the point of observation - can understand the painting's message anymore. Tarnya Cooper's translation of this passage as "because no one can seize me from behind", though neglecting the double meaning of "posterior", seems to grasp this material-describing aspect even better. While this modern perspective on the object may not be a periodically accurate reading, it enables viewing the object's special mechanism when working with an audience.

The text alone charges the picture with an exclusive codification that demands knowledge to be understood. It can already be neglected that the text is only a description of what is painted on the panel, but the question remains if the depicted is not an illustration of the text. A close look at the pictorial elements is now required to get closer to the text-image relation

\section{Image: Opportunity and Time}

Looking at the depiction of the Father Time figure in detail already enlightens its connection to the text (Figure 5). Father Time is an elderly man, naked and only partially covered by a narrow red scarf lying around his shoulder. From his back and his feet, three-coloured wings arise upwards. The figure has a long beard, and an equally long wisp of hair is grown from his forehead. As the figure is only shown from the front, his head's back is only visually indicated to be bald due to the head's slight movement to the left side of the painting. The man's left hand is empty while he holds a crescent-shaped knife in his right hand. With his arms spread to the left and the right, the figure is visually dividing the visual surface, which is met in the separated positioning of the word "TEM: PUS", one part on each side of the figure. If this is designed as a connection to the vertical division of the front-side design in the double-sided painting, has to remain unanswered at this point. 


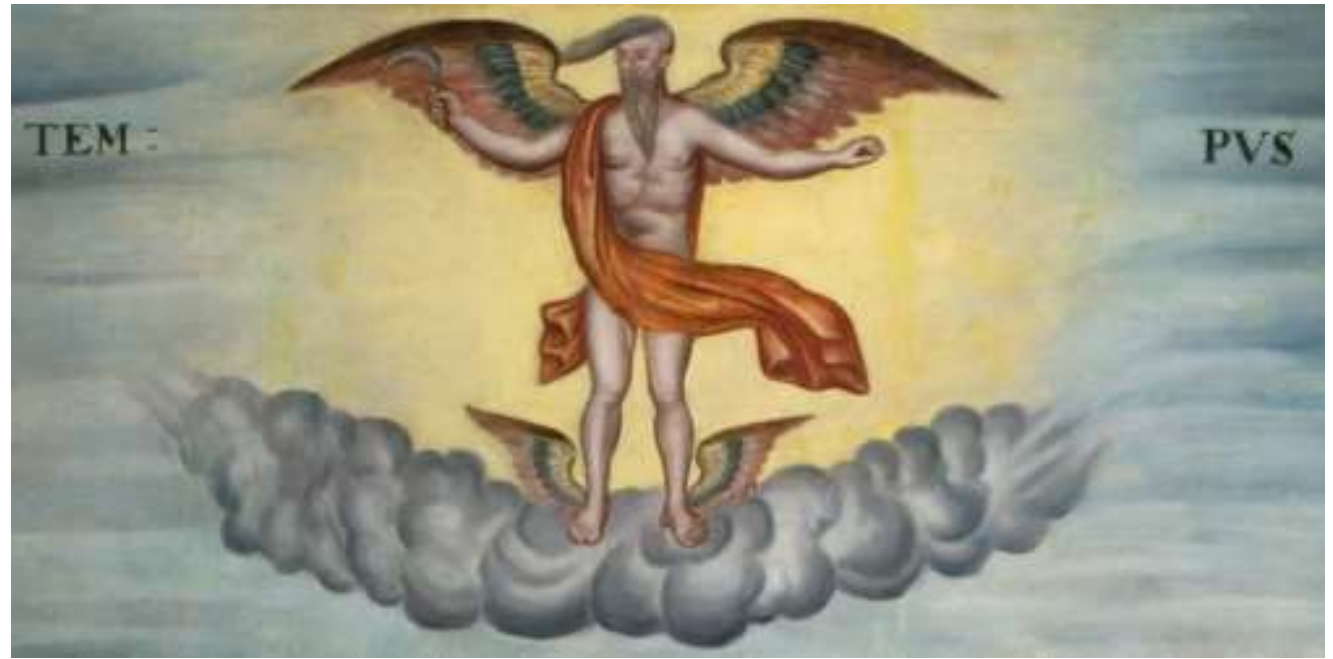

Figure 5. Unknown: Sir Christopher Hatton, c. 1580, Oil on Panel, $96 \times 72.3 \mathrm{~cm}$, Northampton Museums and Art Gallery, Backside, Detail Source: Northampton Museums and Art Gallery.

Overall the expression of lightness, swing and wind is given to the depiction of the figure. The movement of hair, the scarf and the clouds underneath the feat, painted with swift, more and more transparent brushstrokes underline this particular perception. Already, remembering the text, many attributes seem to fit here. When the abstract figure in the inscribed text is asked to comment on its own appearance, it gives information about itself as being positioned at a high place, being swift, holding a knife in its right hand, having long hair hanging from its forehead and the back of the head being bald. All these specifications are met in the figure at the top of Christopher Hatton's picture's backside. But what exactly is presented here? It has already been worked out that the text derives from sources addressing "Occasione", the opportune moment, while this figure is entitled "Time". Additionally, the sources mentioned present different depictions in their emblems. Both Whitney and Alciato present naked long-haired women as figurations (see Figures 3 and 4). A more in-depth look into the iconography is needed to understand the connection of text and image in the double-sided portrait.

In his Studies in Iconology, Erwin Panofsky has given the groundwork description of the personification of Father Time in art history. ${ }^{39}$ Since then, its development has been researched in detail. The depiction of Time as an old bearded man with wings became prominent in humanistic circles and stemmed from the $14^{\text {th }}$ century. In his Trionfo del Tempo, Petrarch gave an illustrious description of the personification of time and the illustrators shaped this in the picture, which was, after Panofsky, the prototype for further depictions. ${ }^{40}$ While

39. Erwin Panofsky, Studies in Iconology: Humanistic Themes in the Art of the Renaissance (New York: Harper \& Row, 1967), 69-93.

40. Cohen, Transformations of Time, 301-306. 
the God Kairos had been a young man in the ancient world and Lysippus' sculpture is described as a youth, Panofsky traced his blending with the older God Saturn during the end of the middle-ages, resulting in the discussed depiction of an older man, the one illustrated in Christopher Hatton's portrait: Naked, a knife in his hand and a long lock hanging from his forehead, Father Time, who is actually Kairos, is a winged figure above the things.

Concerning the connection with Alciato's poem, it is also interesting to point out a second tradition, where Occasion is depicted in a similar way to Father Time but with a shift of genders. Occasion is presented here as a naked female with long hair vividly flying around her shoulders. Such an illustration can be seen in Alciato's as well as in Whitney's book, while both present the already known attributes: knife, scarf, wind. Thus, the tradition of depicting the Occasion, the opportune time as a woman, was prominent in the times of our portrait. What does that mean for the depicted figure of Father Time in Christopher Hatton's picture and the overall text-image connection? It is not a mere quote of Alciato's emblem. Though referring to or at least resembling his poem, the given figuration follows a different pictorial tradition, which ultimately results in the same conclusion. Though labelled as "Time", the figure, even unintentionally, has a connection to the God of the opportune moment and fortune, Kairos. The same reference is made by the text when it reveals itself as a variation of the ancient Kairos-sculpture inscription. To the presented subject of time, the more specific topic of the right moment is added when we combine the meta-text with the pictorial tradition of the depicted figure. The depiction is making the leap from Occasion, also known as a female in contemporary discourse, to old male Father Time. A dialogue inside the object and between object and beholder is opened, a dialogue between youth and old age, the omnipresence of time, and the right moment's elusiveness. The emphasis here seems to lie on time rather than on the opportune moment. But still, both are present thematically in the portrait. But this leap can only be understood when the connection between text and image is made.

\section{Conclusion:}

\section{The Forming of an Emblem or a Dialogue with the Audience}

Without a doubt, the deriving from Alciato's poem and the close connection to emblems and symbols charge the object and make it a demanding one for the audience. Not only are they required to recognise the poem, if not to understand Latin, they also have to deduce its meaning and thus make a connection to the pictorial elements. At last, he is required to put both sides of the object together in the act of perception. When Moseley speaks of a "tension" that the image builds 
up, it can be described with the findings of this study as the exceptional interplay that the inscribed epigram and Father Time's image develop. ${ }^{41}$

It may appear obvious to state that the dialogue presented in the picture's inscription on the back is itself opening the dialogue between image and beholder in return. However, it is a remarkable quality of the text-image-design that, once read, the text is stimulating the perception to a new perspective on the image. In return, if observed closely, the image is not only illustrating but also completing the text in its own manner. Simultaneously, both elements have their own independent function, but in this special combination, they form a bond in this special object. This distinct text image-relation is enrichening and opening the picture to discourses about humanistic subjects such as the figure if Kairos, Time, impermanence, age and death, to name just a few. Barbara Baert has shown how the subject of Kairos experienced an "Aufleben" in the $16^{\text {th }}$ century humanistic circles. ${ }^{42}$ It remains a task for future research to investigate this development, particularly in Elizabethan England. But even if the content of the inscription and the present pictorial tradition is not known, the composition in which text and image are presented is forming an own picture: With the pictorial element positioned at the "highest place", at the top of the panel, and the text written at the lower part of the panel, the composition is visually imitating the well-known form of the emblem, which is, for example, visible in Whitney's and Alciato's publications (see Figures 5 and 6). The typical construction of positioning of "inscription", "picture", and "subscription" - here title, image, and text - is met and implied in the distinct composition of the picture and would have been more apparent to the Elizabethan beholder of a certain circle.

What has been presented here is a proposition of how to capture a complex object and its intertwined image and text-elements. It has been worked out that in the backside of Christopher Hatton's double-sided portrait, firstly, the text hints to sources beyond the depicted and puts the object in a context of ancient and humanistic discourses. Secondly, the pictures are working as a framework and platform for the text and its given information. They represent the overall applicable contextualisation of Christopher Hatton's life and his representation. Thirdly, picture and text have formed elements inside the object, where they have become indistinguishable, a unit, an emblem themselves. Here, a conversion in the form of a dialogue with the beholder is built up. Of course, as said before, this study does not and cannot claim to capture the object as a whole. Too many things have been left unrecognised and not included in these conclusions. For example, the depiction and mention of Lachesis on the backside, which is a highly cryptic element. Moreover, the whole front-side, including the special composition

41. "[...] the painting becomes text to be interpreted and text becomes visual sign in its own right," Moseley, "A Portrait of Sir Christopher Hatton," 377.

42. Barbara Baert, "Kairos: Nachleben, Ikonographie und Hermeneutik," Das Münster 70 (2017): 144. 
of Christopher Hatton's portrait, could not have been addressed here. Furthermore, the abstract idea of Kairos, Fortune and Occasion seems to fit the biographical legends known about Christopher Hatton. But this remains a clue to the overall interpretation of the portrait. This study remains a segment and an initiator of a more complex and more demanding object, which deserves further research.

\section{Acknowledgments}

This article is based on and part of my doctoral project Image and Secrecy in Elizabethan England at the University of Konstanz. Thank you to the Northampton Museum and Art Gallery for the kind permission to use their images.

\section{Bibliography}

Alciato, Andrea. Emblematum liber. London: Scolar Press, 1995.

Aston, Margaret. "Gods, Saints and Reformers: Portraiture and Protestant England." In Albion's Classicism: The Visual Arts in Britain 1550-1660, edited by Lucy Gent, 181-220. New Haven: Yale University Press, 1995.

Aston, Margaret. The King's Bedpost. Cambridge: Cambridge University Press, 1996.

Auerbach, Erna. Tudor Artists: A Study of Painters in the Royal Service and of Portraiture on Illuminated Documents from the Accession of Henry VIII to the Death of Elizabeth I. London: Athlone Press, 1954.

Baert, Barbara. "Kairos: Nachleben, Ikonographie und Hermeneutik." [Kairos: Afterlife, Iconography and Hermeneutics.] Das Münster 70 (2017): 130-144.

Beer, Arthur. "Astronomical Dating of Works of Art. "Vistas in Astronomy 9 (1968): 177-223. Brooks, Eric St John. Sir Christopher Hatton. Queen Elizabeth's Favourite. London: Cape, 1947.

Cohen, Simona. Transformations of Time and Temporality in Medieval and Renaissance Art. Leiden: Brill, 2014.

Cooper, Tarnya. Citizen Portrait. Portrait Painting and the Urban Elite of Tudor and Jacobean England and Wales. Yale University Press, 2012.

Cooper, Tarnya. Elizabeth I \& her People. London: National Portrait Gallery, 2013.

Cox, Lindsey. Pleasing 'the Common Sort Exceedingly Well': An Interdisciplinary Repositioning of the British Portrait Miniature c. 1520-1650. PhD Dissertation. University of Kent, 2018.

Daly, Peter. Andrea Alciato in England: Aspects of the Reception of Alciato's Emblems in England. New York: AMS Press, 2013.

Deacon, Malcolm. The Courtier \& The Queen: Sir Christopher Hatton and Elizabeth I. Northampton: Park Lane Publishing, 2008.

Flemming, Juliet, "Wounded Walls: Graffiti, Grammatology, and the Age of Shakespeare." Criticism 39, (1997): 1-30.

Hearn, Karen. "Introduction." In Dynasties: Painting in Tudor and Jacobean England 15301630, edited by Karen Hearn, 9-10. Peterborough: Tate Publications, 1995. 
Moseley, C. W. "A Portrait of Sir Christopher Hatton, Erasmus and an Emblem of Alciato: Some Questions." The Antiquaries Journal 86, (2006): 373-379.

Nicolas, Nicholas Harris. Memoirs of the Life and Times of Sir Christopher Hatton, K. G. London: Bentley, 1847.

Panofsky, Erwin. Studies in Iconology: Humanistic Themes in the Art of the Renaissance. New York: Harper \& Row, 1967.

Praz, Mario. Studies in Seventeenth-Century Imagery. Rome: Edizioni di Storia e Letteratura, 1975.

Strong, Roy. "Elizabethan Painting: An Approach through Inscriptions - Robert Peake the Elder." The Burlington Magazine 105 (1963): 53-57.

Strong, Roy. The Elizabethan Image: Painting in England 1540-1620. London: Tate Gallery Publications, 1969.

Vines, Alice Gilmore. Neither Fire nor Steel. Sir Christopher Hatton. Chicago: Nelson-Hall, 1978.

Whitney, Geoffrey. Choice of Emblemes. London: Lovell Reeve, 1866.

Wright, Thomas. Queen Elizabeth and her Times, Original Letters Selected from the Private Correspondence of Burghley [and Others]. Volume 2. London: Henry Colburn, 1838. 